\title{
Vegetation Characteristics of Mountain and Wyoming Big Sagebrush Plant Communities in the Northern Great Basin
}

\author{
Kirk W. Davies and Jon D. Bates \\ Authors are Rangeland Scientists, US Department of Agriculture-Agricultural Research Service, Eastern Oregon Agricultural Research Center, \\ Burns, OR 97720, USA.
}

\begin{abstract}
Dominant plant species are often used as indicators of site potential in forest and rangelands. However, subspecies of dominant vegetation often indicate different site characteristics and, therefore, may be more useful indicators of plant community potential and provide more precise information for management. Big sagebrush (Artemisia tridentata Nutt.) occurs across large expanses of the western United States. Common subspecies of big sagebrush have considerable variation in the types of sites they occupy, but information that quantifies differences in their vegetation characteristics is lacking. Consequently, wildlife and land management guidelines frequently do not differentiate between subspecies of big sagebrush. To quantify vegetation characteristics between two common subspecies of big sagebrush, we sampled 106 intact big sagebrush plant communities. Half of the sampled plant communities were Wyoming big sagebrush (A. tridentata subsp. wyomingensis [Beetle \& A. Young] S. L. Welsh) plant communities, and the other half were mountain big sagebrush (A. tridentata subsp. vaseyana [Rydb.] Beetle) plant communities. In general, mountain big sagebrush plant communities were more diverse and had greater vegetation cover, density, and biomass production than Wyoming big sagebrush plant communities. Sagebrush cover was, on average, 2.4-fold higher in mountain big sagebrush plant communities. Perennial forb density and cover were 3.8- and 5.6-fold greater in mountain compared to Wyoming big sagebrush plant communities. Total herbaceous biomass production was approximately twofold greater in mountain than Wyoming big sagebrush plant communities. The results of this study suggest that management guidelines for grazing, wildlife habitat, and other uses should recognize widespread subspecies as indicators of differences in site potentials.
\end{abstract}

\section{Resumen}

Las especies de plantas dominantes se usan frecuentemente como indicadores de potencial en sitios de bosques y pastizales. Sin embargo, las subespecies de vegetación dominante a menudo indican diferentes características y entonces, pueden ser indicadores más útiles del potencial de una comunidad de plantas, ya que dan información más precisa para su manejo. Big sagebrush (Artemisia tridentata Nutt.) se encuentra presente en grandes extensiones a través del oeste de Estados Unidos. Especies comunes de big sagebrush tienen considerables variaciones en cuanto al tipo de lugares en las que están presentes, sin embargo, es escasa la información que cuantifique estas diferencias en cuanto a sus características vegetativas. En consecuencia, las directrices para el manejo de fauna y de la tierra no hacen diferencia entre subespecies de big sagebrush. Para cuantificar las características vegetativas entre dos subespecies comunes de big sagebrush, obtuvimos muestras de 106 plantas de comunidades intactas de big sagebrush. La mitad de las plantas muestreadas se obtuvieron de comunidades de Wyoming big sagebrush $(A$. tridentata subsp. wyomingensis [Beetle \& A. Young] S. L. Welsh) y la otra mitad se seleccionó de una comunidad de mountain big sagebrush (A. tridentata subsp. vaseyana [Rydb.] Beetle). La cobertura de Sagebrush fue 2.4 veces mayor en promedio en las comunidades de mountain big sagebrush. La densidad y cobertura de herbáceas perennes fue 3.8 y 5.6 veces mayor en mountain sagebrush comparada con las comunidades de Wyoming big sagebrush. La biomasa total producida por las herbáceas fue aproximadamente 2 veces mayor en comunidades de plantas de mountain big sagebrush que en las comunidades de Wyoming big sagebrush. Los resultados de este estudio sugieren que las directrices para el manejo de pastoreo, fauna y otros usos deben reconocer la amplia variabilidad de subespecies como indicadores en sitios con diferentes potenciales.

Key Words: Artemisia tridentata, diversity, habitat, herbaceous cover, sage-grouse

\section{INTRODUCTION}

Dominant plant species provide important information about the vegetation characteristics and potentials of a site. In some situations, widespread subspecies, which vary in the site conditions that they inhabit, can also provide valuable insight into plant community characteristics and site vegetation

\footnotetext{
Correspondence: Kirk Davies, US Department of Agriculture-Agricultural Research Service, Eastern Oregon Agricultural Research Center, 67826-A Hwy 205, Burns, OR 97720, USA. Email: kirk.davies@oregonstate.edu

Manuscript received 5 May 2009; manuscript accepted 14 February 2010.
}

potentials. In the sagebrush (Artemisia L.) biome, subspecies of big sagebrush (Artemisia tridentata Nutt.) occupy different sites (Blaisdell et al. 1982; Tisdale 1994). However, direct quantitative comparisons of vegetation characteristics among plant communities occupied by different big sagebrush subspecies are lacking.

More information describing the vegetation characteristics of plant communities inhabited by the different subspecies of big sagebrush is needed because of the amount of area occupied by these communities and their importance to sagebrush obligate and facultative wildlife species as well as the livestock industry. Sagebrush plant communities occupy over 62 million ha in the 
western United States (Küchler 1970; Miller et al. 1994; West and Young 2000). The most widely distributed and abundant species of this genus is big sagebrush (Miller and Eddleman 2000). Two of the most common subspecies of big sagebrush are Wyoming (Artemisia tridentata subsp. wyomingensis [Beetle \& A. Young] S. L. Welsh) and mountain big sagebrush (Artemisia tridentata subsp. vaseyana [Rydb.] Beetle).

Differences in vegetation characteristics between mountain and Wyoming big sagebrush plant communities could be critical in determining their potential value as wildlife habitat and for prioritizing and prescribing management. Greater sagegrouse (Centrocercus urophasianus) and other sagebrush obligate wildlife species require sagebrush plant communities for survival and to complete their life cycles (Wallestad et al. 1975; Shipley et al. 2006). Other wildlife species, including mule deer (Odocoileus hemionus) and pronghorn (Antilocapra americana), can depend heavily on big sagebrush plant communities for habitat (Mason 1952; Austin and Urness 1983). Thus, correctly identifying vegetation potentials and habitat values of plant communities inhabited by the different subspecies of big sagebrush are needed. However, subspecies of big sagebrush are often agglomerated when wildlife and grazing management guidelines are developed because of a lack of information detailing vegetation differences between plant communities dominated by the different subspecies. For example, recently developed guidelines for sage-grouse habitat management (Connelly et al. 2000) did not distinguish between subspecies of big sagebrush and were beyond the ecological potential of many intact Wyoming big sagebrush communities (Davies et al. 2006). Combining information from mountain and Wyoming big sagebrush plant communities may have, in part, contributed to the guidelines' vegetation requirements being beyond the potential of many Wyoming big sagebrush plant communities. Thus, management of these communities for sagebrush obligate and facultative wildlife species, livestock grazing, and other uses could be improved with more information detailing the differences in vegetation characteristics between mountain big sagebrush and Wyoming big sagebrush communities.

Environmental differences between mountain and Wyoming big sagebrush plant communities have been identified. Mountain big sagebrush plant communities are generally found at higher elevations and in more cool and mesic environments than Wyoming big sagebrush plant communities (Winward and Tisdale 1977; West et al. 1978; Winward 1980; Blaisdell et al. 1982; Hironaka et al. 1983). Wyoming big sagebrush plant communities occupy xeric foothills and valleys with moderate to shallow soils at elevations of 700-2150 m (Morris et al. 1976; Winward and Tisdale 1977; Hironaka 1978; McArthur and Plummer 1978; Blaisdell et al. 1982; Tisdale 1994). Whereas, mountain big sagebrush plant communities typically inhabit foothills and mountain slopes between $1200 \mathrm{~m}$ and $3000 \mathrm{~m}$ in elevation on deep, well-drained soils (Winward 1980; Blaisdell et al. 1982; Tisdale 1994). Mountain big sagebrush plant communities tend to be found on more fertile soils with a better developed mollic epipedon than Wyoming big sagebrush plant communities (Jensen et al. 1988; Jensen 1989). However, vegetation differences between mountain and Wyoming big sagebrush plant communities have not been well quantified.
The few reported differences in vegetation characteristics between mountain and Wyoming big sagebrush plant communities were only general observations, lacking actual data and comparisons. Hironaka et al. (1983) observed that mountain big sagebrush tends to produce more foliar cover and occur at greater densities than other big sagebrush subspecies. Compared with Wyoming big sagebrush, Winward and Tisdale (1977) speculated that mountain big sagebrush demonstrates a greater tendency to increase in density and cover. Mountain big sagebrush communities may have greater amounts of perennial forbs than Wyoming big sagebrush communities. Winward (1980) observed few perennial forbs in Wyoming big sagebrush plant communities and many species of forbs in mountain big sagebrush plant communities. However, actual quantitative comparisons of vegetation characteristics between mountain big sagebrush and Wyoming big sagebrush plant communities are lacking.

The objective of this study was to quantify vegetation differences between mountain big sagebrush and Wyoming big sagebrush plant communities. We hypothesized that mountain big sagebrush plant communities compared to Wyoming big sagebrush plant communities would have 1) greater herbaceous vegetation diversity, production, density, and cover; 2) less bare ground, biotic crusts, and moss; and 3) greater sagebrush density and cover.

\section{METHODS}

\section{Study Area}

The study area encompassed 1500000 ha in the High Desert Ecological Province (Anderson et al. 1998) in southeastern Oregon between Brothers, Oregon; Lakeview, Oregon; Burns, Oregon; and Denio, Nevada. Dominant shrub vegetation at all study sites was either mountain or Wyoming big sagebrush. Climate across the study area is characterized by cool, wet winters and springs, and hot, dry summers. Regional precipitation during 2007 and 2008 was approximately $80 \%$ and $66 \%$ of the $40-\mathrm{yr}$ long-term average precipitation, respectively. Common perennial grasses in Wyoming big sagebrush plant communities included Idaho fescue (Festuca idahoensis Elmer), prairie junegrass (Koeleria macrantha [Ledeb.] J. A. Schultes), bluebunch wheatgrass (Pseudoroegneria spicata [Pursh] A. Löve), Thurber's needlegrass (Achnatherum thurberianum [Piper] Barkworth), needle and thread (Hesperostipa comata [Trin. \& Rupr.] Barkworth), squirreltail (Elymus elymoides [Raf.] Swezey), and Sandberg bluegrass (Poa secunda J. Presl). Common perennial grasses in mountain big sagebrush plant communities included Idaho fescue, prairie junegrass, bluebunch wheatgrass, Thurber's needlegrass, Columbia needlegrass (Achnatherum nelsonii [Scribn.] Barkworth), mountain brome (Bromus marginatus Nees ex Steud.), squirreltail, and Sandberg bluegrass. Common perennial forbs in both mountain and Wyoming big sagebrush plant communities included hawksbeard (Crepis L. spp.), biscuitroot (Lomatium Raf. spp.), milkvetch (Astragalus L. spp.), and lupine (Lupinus L. spp.). Study sites had limited use by livestock and were considered intact plant communities using criteria from Davies et al. (2006). Elevation averaged $1863 \mathrm{~m}$ and $1537 \mathrm{~m}$ above sea level in the mountain big sagebrush and Wyoming big 
sagebrush plant communities sampled, respectively. In the mountain big sagebrush and Wyoming big sagebrush plant communities sampled, elevation ranged from $1601 \mathrm{~m}$ to $2164 \mathrm{~m}$ and $1307 \mathrm{~m}$ to $1796 \mathrm{~m}$ above sea level, respectively. Soils were variable across the study area and included Aridisols, Mollisols, and Andisols. Slope and aspect varied among the study sites. Minimal and maximum distance between sampled communities was $0.9 \mathrm{~km}$ and $210 \mathrm{~km}$, respectively.

\section{Experimental Design}

One hundred and six big sagebrush plant communities were sampled that met the criteria in Davies et al. (2006) for intact big sagebrush plant communities. Sampling occurred during the growing season (from June through early July) in 2007 and 2008. Half of the plant communities sampled were mountain big sagebrush communities, and the other half were Wyoming big sagebrush communities. All plant communities that met the criteria of intact big sagebrush plant communities were sampled. Response variables include vegetation cover, density, production, and species richness and diversity.

One randomly located $80 \times 50 \mathrm{~m}$ plot $(0.4 \mathrm{ha})$ was used to sample each plant community. Five 50-m transects, spaced at 20-m intervals, were deployed along an 80-m transect. Shrub canopy cover by species was measured using the line intercept method (Canfield 1941) on each of the 50-m transects. Canopy gaps less than $15 \mathrm{~cm}$ were included in the shrub canopy cover measurements. Shrub density was measured by species by counting all the shrubs rooted inside five $2 \times 50 \mathrm{~m}$ belt transects. The belt transects were deployed along each of the five 50-m transects spaced at 20-m intervals. Herbaceous canopy cover was visually estimated by species to the nearest $1 \%$ inside $40 \times 50 \mathrm{~cm}$ frames $\left(0.2 \mathrm{~m}^{2}\right)$ located at $3-\mathrm{m}$ intervals on each $50-\mathrm{m}$ transect (starting at $3 \mathrm{~m}$ and ending at $45 \mathrm{~m}$ ), resulting in 15 frames per transect and 75 frames per plot. Bare ground, litter, moss, and biological crust cover were also visually estimated inside the $40 \times 50 \mathrm{~cm}$ frames. Herbaceous perennial vegetation density was measured by species inside the $7540 \times 50 \mathrm{~cm}$ frames. Species richness was determined by summing all species found in the $40 \times 50 \mathrm{~cm}$ frames at each site. Herbaceous vegetation diversity was calculated from species density measurements using the Shannon diversity index (Krebs 1998). Herbaceous biomass production by life-form (perennial or annual) was determined by clipping, oven drying, and then weighing the current year's growth from 25 randomly located $1-\mathrm{m}^{2}$ frames per plot.

\section{Statistical Analysis}

Analysis of variance (S-Plus v. 8.0 2007, Insight Corp, Seattle, WA) was used to test for vegetation differences between mountain big sagebrush and Wyoming big sagebrush plant communities. Data were tested for normality using the univariate procedure. Dominant big sagebrush subspecies and year were used as explanatory factors. Year was used as a covariate, but was not an effect of interest. Differences between means were considered significant if $P$ values were $\leq 0.05$. Means are reported with standard errors (mean $\pm S E$ ). Plant functional groups were used in some of the analyses to simplify analysis and permit comparisons among sites with different

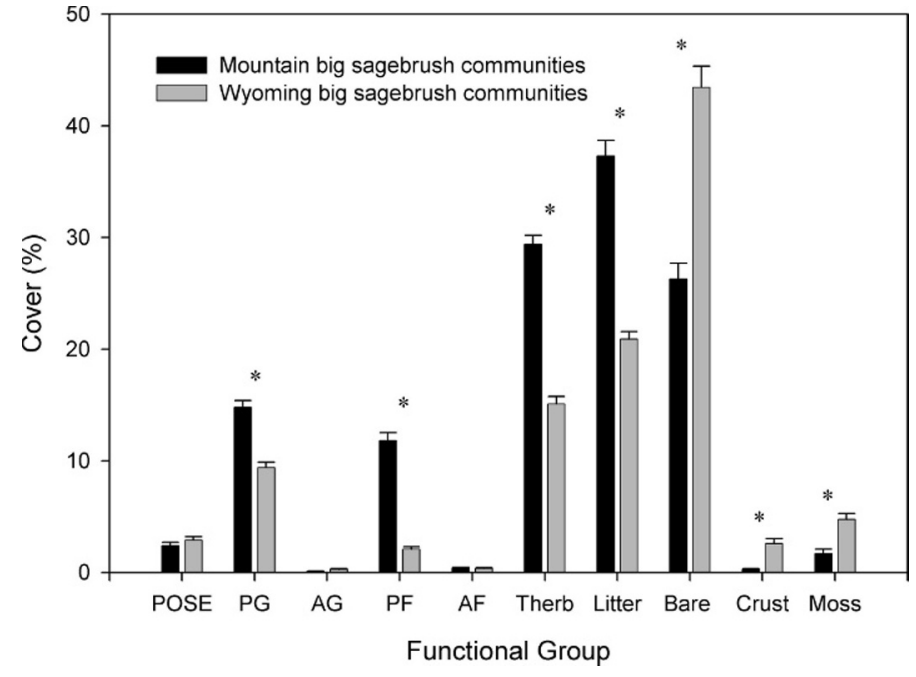

Figure 1. Plant functional group cover values (mean $+\mathrm{SE}$ ) in mountain big sagebrush and Wyoming big sagebrush communities. POSE indicates Sandberg bluegrass; PG, large perennial bunchgrass; $A G$, annual grass; PF, perennial forb; AF, annual forb; Therb, total herbaceous vegetation; Litter, litter; Bare, bare ground; Crust, biological crusts; and Moss, moss. Asterisks $\left({ }^{*}\right)$ indicate significant difference $(P<0.05)$ in cover for that functional group between mountain and Wyoming big plant communities.

plant species composition (Boyd and Bidwell 2002; Davies et al. 2007b). Plant functional groups used were Sandberg bluegrass, large perennial bunchgrasses, annual grasses, perennial forbs, and annual forbs. Sandberg bluegrass was treated as a separate functional group from the other perennial bunchgrasses because it has a more rapid phenological development, acquires resources over a shorter period of time, and is of shorter stature than the large perennial bunchgrasses in these ecosystems (Davies 2008; James et al. 2008). For analysis of biomass production, herbaceous species were grouped according to life-form (annual or perennial).

\section{RESULTS}

\section{Cover}

Perennial and total vegetation cover were generally greater in mountain big sagebrush compared to Wyoming big sagebrush plant communities, while annual vegetation cover values were similar (Fig. 1). Large perennial bunchgrass and perennial forb cover were 1.6- and 5.6-fold, respectively, greater in mountain big sagebrush than Wyoming big sagebrush communities $(P<0.01)$. Sandberg bluegrass, annual grass, and annual forb cover values did not vary by sagebrush plant community $(P>0.05)$. Litter and total herbaceous cover values were approximately 1.8- and 1.9-fold, respectively, higher in mountain big sagebrush compared to Wyoming big sagebrush communities $(P<0.01)$. Bare ground, biological crust, and moss cover were 1.6-, 9.5-, and 2.9-fold, respectively, greater in Wyoming big sagebrush compared to mountain big sagebrush communities $(P<0.01)$.

Sagebrush cover was approximately 2.4-fold greater in mountain big sagebrush than Wyoming big sagebrush commu- 
Table 1. Shrub cover values in mountain and Wyoming big sagebrush communities. Different lowercase letters indicate significant difference between subspecies $(P<0.05)$.

\begin{tabular}{|c|c|c|c|c|c|c|}
\hline \multirow[b]{2}{*}{ Statistical parameter } & \multicolumn{3}{|c|}{ Mountain big sagebrush cover (\%) } & \multicolumn{3}{|c|}{ Wyoming big sagebrush cover (\%) } \\
\hline & Sagebrush & Other shrub & Green rabbitbrush & Sagebrush & Other shrub & Green rabbitbrush \\
\hline Mean \pm SE & $23.0 \pm 1.1^{\mathrm{b}}$ & $3.2 \pm 0.4^{b}$ & $1.9 \pm 0.2$ & $9.7 \pm 0.6^{a}$ & $1.9 \pm 0.3^{a}$ & $1.6 \pm 0.3$ \\
\hline Minimum & 9.1 & 0.0 & 0.0 & 3.6 & 0.0 & 0.0 \\
\hline Maximum & 41.7 & 12.1 & 5.9 & 19.7 & 8.5 & 6.2 \\
\hline
\end{tabular}

nities $(P<0.01$; Table 1$)$. Similarly, other shrub species (all shrubs excluding sagebrush) cover was also greater in the mountain big sagebrush compared to the Wyoming big sagebrush communities $(P=0.01)$. However, green rabbitbrush (Chrysothamnus viscidiflorus [Hook.] Nutt.) cover was not different between the big sagebrush plant communities $(P=0.26)$.

\section{Density}

Perennial herbaceous vegetation densities were generally higher in mountain big sagebrush compared to Wyoming big sagebrush plant communities (Fig. 2). Large perennial bunchgrass density was almost twice as great in mountain big sagebrush compared to Wyoming big sagebrush plant communities $(P<0.01)$. Similarly, perennial forb and total perennial herbaceous vegetation densities were greater in mountain big sagebrush than Wyoming big sagebrush plant communities $(P<0.01)$. Perennial forb density was 3.8 -fold greater in mountain big sagebrush plant communities. Total perennial herbaceous density was more than 1.6-fold higher in mountain big sagebrush compared to Wyoming big sagebrush plant communities. In contrast, Wyoming big sagebrush plant communities had approximately twice the density of Sandberg bluegrass compared to mountain big sagebrush plant communities $(P<0.01)$.

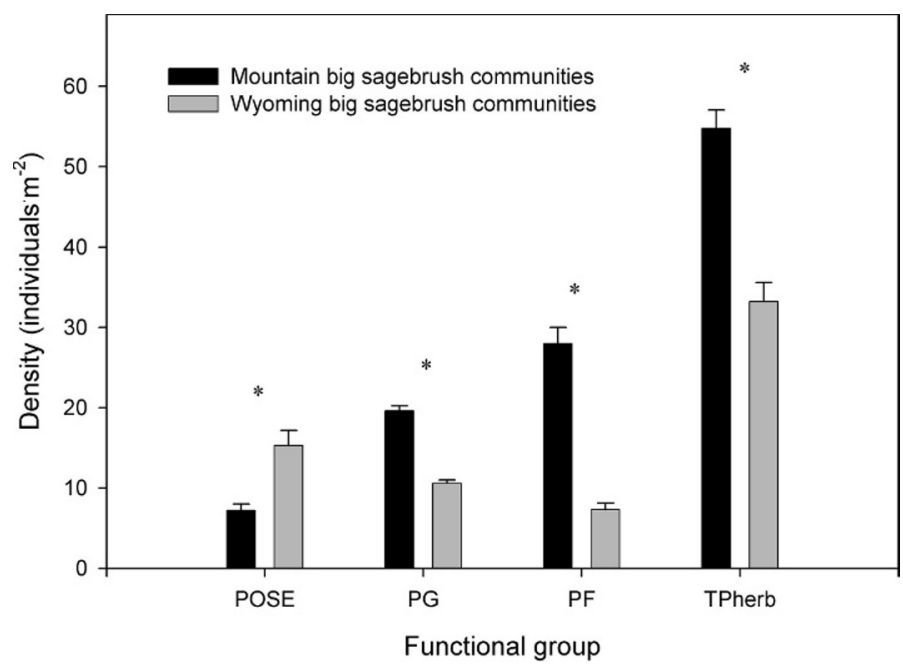

Figure 2. Plant functional group densities (mean + SE) in mountain big sagebrush and Wyoming big sagebrush communities. POSE indicates Sandberg bluegrass; PG, large perennial bunchgrass; PF, perennial forb; and TPherb, total perennial herbaceous vegetation. Asterisks $\left({ }^{*}\right)$ indicate significant difference $(P<0.05)$ in density for that functional group between mountain and Wyoming big plant communities.
Sagebrush density was 2-fold higher in mountain big sagebrush communities $\left(1.1 \pm 0.06\right.$ individuals $\left.\cdot \mathrm{m}^{-2}\right) \mathrm{com}$ pared to Wyoming big sagebrush communities $(0.5 \pm 0.05$ individuals $\left.\cdot \mathrm{m}^{-2} ; P<0.01\right)$. However, other shrub and green rabbitbrush densities did not vary by big sagebrush plant community $(P=0.42$ and 0.84 , respectively).

\section{Production and Diversity}

Mountain big sagebrush plant communities produced more herbaceous biomass than Wyoming big sagebrush plant communities (Fig. 3). Total herbaceous and perennial herbaceous biomass production was approximately twofold higher in the mountain big sagebrush compared to Wyoming big sagebrush plant communities $(P<0.01)$. However, annual herbaceous biomass production did not differ between the big sagebrush plant communities $(P=0.32)$.

Perennial herbaceous species richness and diversity were greater in mountain big sagebrush compared to Wyoming big sagebrush plant communities $(P<0.01)$. Perennial herbaceous species diversity averaged $2.4 \pm 0.04$ and $1.6 \pm 0.05$ (Shannon diversity index) in mountain big sagebrush and Wyoming big sagebrush plant communities, respectively. Perennial herbaceous species richness averaged $24.9 \pm 0.78$ and $14.4 \pm 0.64$ in mountain big sagebrush and Wyoming big sagebrush plant communities, respectively.

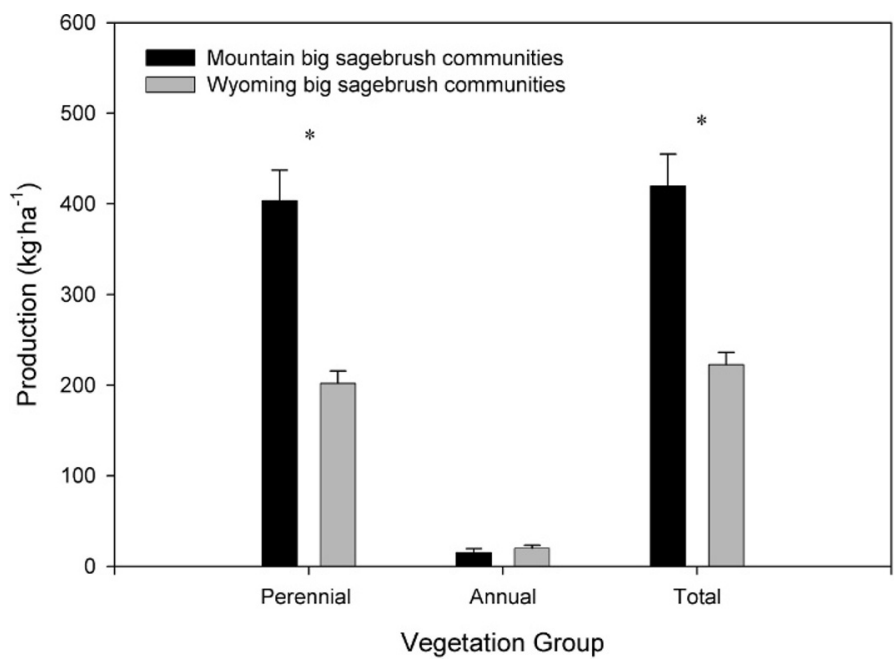

Figure 3. Biomass production values (mean $+\mathrm{SE}$ ) in mountain big sagebrush and Wyoming big sagebrush communities. Perennial indicates perennial herbaceous vegetation; Annual, annual herbaceous vegetation; and Total, total herbaceous vegetation. Asterisks $\left(^{*}\right)$ indicate significant difference $(P<0.05)$ in production for that vegetation group between mountain and Wyoming big plant communities. 


\section{DISCUSSION}

The results of this study suggest that widespread subspecies of dominant vegetation can be useful indicators of site potential and provide valuable information for management. The differences in vegetation characteristics suggest that management plans and habitat guidelines should recognize widespread subspecies of dominant vegetation. In our study, mountain big sagebrush plant communities were generally more productive and diverse than Wyoming big sagebrush plant communities. The potential value of mountain big sagebrush and Wyoming big sagebrush plant communities for wildlife habitat also varied based on differences in vegetation characteristics.

The differences in vegetation characteristics between mountain big sagebrush and Wyoming big sagebrush communities indicated that extrapolating vegetation potentials from one subspecies of big sagebrush to another is not appropriate. For example, Davies et al. (2006) found many Wyoming big sagebrush plant communities did not meet the vegetation requirements in recently developed sage-grouse habitat guidelines (Connelly et al. 2000). However, our results suggest that the mountain big sagebrush communities are more likely to meet the guideline requirements, because they produce more sagebrush cover and greater amounts of perennial forbs and large bunchgrasses. The vegetation characteristics of mountain and Wyoming big sagebrush communities were substantially different. Our results support speculation by Windward and Tisdale (1977) and Hironaka et al. (1983) that mountain big sagebrush plant communities have a greater potential to produce greater sagebrush cover and density than Wyoming big sagebrush plant communities.

Mountain big sagebrush plant communities produced more forage and hiding cover for wildlife than Wyoming big sagebrush plant communities. However, these benefits may not be realized in the winter because of potentially more adverse winter conditions in mountain big sagebrush plant communities. Wyoming big sagebrush plant communities often provide critical winter wildlife habitat because they generally occur at lower elevations, experience warmer temperatures, and accumulate less snow than adjacent higher elevation/more productive summer habitats (Burke et al. 1989; Homer et al. 1993; Connelly et al. 2000). The greater diversity of perennial herbaceous vegetation also suggests that mountain big sagebrush plant communities would potentially meet the habitat needs of a greater diversity of animals. The results of this study suggest that mountain big sagebrush and Wyoming big sagebrush plant communities vary considerably in the wildlife habitat they provide during the growing season.

Greater vegetation cover, density, production, and diversity in mountain big sagebrush compared to Wyoming big sagebrush plant communities are probably due to conditions being more favorable for vegetation growth on sites occupied by mountain big sagebrush. Mountain big sagebrush plant communities are generally found in cooler and more mesic environments than Wyoming big sagebrush (Winward and Tisdale 1977; West et al. 1978; Winward 1980; Blaisdell et al. 1982; Hironaka et al. 1983). Davies et al. (2007a) reported that herbaceous and total vegetation cover values were correlated positively to site conditions that are indicative of greater soil water (less direct radiation and greater soil water holding capacity) across Wyoming big sagebrush plant communities. Wyoming big sagebrush density was correlated positively to increasing elevation in the northern Great Basin (Davies et al. 2007a). Thus, mountain big sagebrush communities probably produce greater amounts of vegetation compared to Wyoming big sagebrush communities because they tend to occur on locations with a more mesic moisture regime.

Dissimilar to perennial vascular plants, biological soil crust and moss cover values were lower in mountain big sagebrush compared to Wyoming big sagebrush plant communities, suggesting that the influence of biological crust and moss are less in mountain big sagebrush communities. Our results agree with Ponzetti and McCune (2001) that warm, lower elevation sites have greater crust cover. This may be partially due to the crust being able to grow during the winter and early spring when moisture is more available (Ponzetti and McCune 2001) and that there is more bare ground to occupy in warm, lower elevation Wyoming big sagebrush plant communities compared to cooler, higher elevation mountain big sagebrush plant communities. However, biological soil crusts do not appear to constitute a large portion of cover in either mountain or Wyoming big sagebrush plant communities in the northern Great Basin.

Our data provide important information on the differences in vegetation characteristics between mountain big sagebrush and Wyoming big sagebrush plant communities. However, differences may become even more divergent in wetter years. We speculate that because of the greater diversity and density of perennial vegetation in mountain big sagebrush compared to Wyoming big sagebrush plant communities, that in wetter years, mountain big sagebrush would be able to better utilize the increased water availability and differences between the subspecies plant communities would become larger. Plant functional group diversity is important to utilizing available resources (Davies et al. 2007b). Differences may also have been more pronounced if we had sampled along a more extreme elevation gradient. Despite these limitations, important differences in vegetation characteristics and habitat values have been identified between mountain big sagebrush and Wyoming big sagebrush plant communities.

\section{MANAGEMENT IMPLICATIONS}

This study suggests that widespread subspecies can provide useful information about site vegetation potentials. Differences in the sites occupied by subspecies can result in significantly different vegetation characteristics at the community level. Thus, by identifying the subspecies of dominant vegetation, potential community vegetation characteristics can be more accurately predicted. In our study, mountain big sagebrush plant communities were more productive and diverse than Wyoming big sagebrush plant communities. The differences in vegetation suggest that these plant communities produce distinct types and varying quality of wildlife habitat. The differences between mountain and Wyoming big sagebrush plant communities should be recognized in management plans and guidelines for wildlife habitat. This study provided evidence that suggests that agglomerating subspecies of big sagebrush for management is not advised. 


\section{ACKNOWLEDGMENTS}

The authors are grateful to summer crews for their hard work collecting data for this study. The authors also appreciated the time and efforts of Aleta Nafus and Georjanna Pokorney for managing the data. Thoughtful reviews of this manuscript by S. Petersen, D. Johnson, and C. Boyd were greatly appreciated. The authors also thank the anonymous reviewers for providing useful comments and suggestions on this manuscript. The authors also thank Burns- and Lakeview-District Bureau of Land Management and the Hart Mountain National Antelope Refuge for providing land for this research project. The authors also appreciated Gail Collins's and Paul Steblein's assistance in accessing intact big sagebrush communities on the Hart Mountain National Antelope Refuge.

\section{LITERATURE CITED}

Anderson, E. W., M. M. Borman, and W. C. Krueger. 1998. The ecological provinces of Oregon: a treatise on the basic ecological geography of the state. Corvallis, OR, USA: Oregon Agricultural Experiment Station. 138 p.

Austin, D. D., And P. J. Unness. 1983. Overwinter forage selection by mule deer on a seeded big sagebrush-grass range. Journal of Wildlife Management 47:1203-1207.

Blaisdell, J. P., R. B. Murry, and E. D. McArthur. 1982. Managing Intermountain rangelands: sagebrush-grass ranges. Ogden, UT, USA: USDA Intermountain Forest and Range Experiment Station, General Technical Report INT-134. 41 p.

BoYd, C. S., AND T. G. BidWELL. 2002. Effects of prescribed fire on shinnery oak plant communities in western Oklahoma. Restoration Ecology 10:324-333.

Burke, I. C., W. A. Reiners, and R. K. Olson. 1989. Togographic control in a mountain big sagebrush steppe. Vegetation 84:77-86.

Canfield, R. H. 1941. Application of the line interception methods in sampling range vegetation. Journal of Forestry 39:388-394.

Connelly, J. W., M. A. Schroeder, A. R. Sands, and C. E. Braun. 2000. Guidelines to manage sage-grouse populations and their habitat. Wildlife Society Bulletin 28:967-985.

DAvies, K. W. 2008. Medusahead dispersal and establishment in sagebrush steppe plant communities. Rangeland Ecology and Management 61:110-115.

Davies, K. W., J. D. Bates, and R. F. Miller. 2006. Vegetation characteristics across part of the Wyoming big sagebrush alliance. Rangeland Ecology and Management 59:567-575.

Davies, K. W., J. D. Bates, and R. F. Miller. 2007a. Environmental and vegetation characteristics of the Artemisia tridentata spp. wyomingensis alliance. Journal of Arid Environments 70:478-494.

Davies, K. W., M. L. Pokorny, R. L. Sheley, and J. J. James. 2007b. Influence of plant functional group removal on soil inorganic nitrogen concentrations in native grasslands. Rangeland Ecology and Management 60:304-310.

HironakA, M. 1978. Basic synecological relationships of the Columbia River sagebrush type. In: G. F. Gifford, F. E. Busby, and J. D. Shaw [EDS.]. Sagebrush ecosystem symposium. Logan, UT, USA: Utah State University Press. p. 27-32.

Hironaka, M. M., M. Fosberg, and A. H. Winward. 1983. Sagebrush-grass habitat types of southern Idaho. Moscow, ID, USA: University of Idaho, Bulletin $35.41 \mathrm{p}$.

Homer, C. G., T. C. Edwards, R. D. Ramsey, and K. P. Price. 1993. Use of remote sensing methods in modeling sage grouse winter habitat. Journal of Wildlife Management 57:78-84.
James, J. J., K. W. Davies, R. L. Sheley, and Z. T. Aanderud. 2008. Linking nitrogen partitioning and species abundance to invasion resistance in the Great Basin. Oecologia 156:637-648.

JensEN, M. E. 1989. Soil characteristics of mountainous northeastern Nevada sagebrush community types. Great Basin Naturalist 49:469-481.

Jensen, M. E., L. S. Peck, and M. V. Wilson. 1988. A sagebrush community type classification for mountainous northeastern Nevada rangelands. Great Basin Naturalist 48:422-433.

KREBS, C. J. 1998. Ecological methodology. 2nd ed. Menlo Park, CA, USA: Benjamin Cummings. $624 \mathrm{p}$.

Küchler, A. W. 1970. Potential natural vegetation. In: A. C. Gerlach [ed.]. The national atlas of U.S.A. Washington, DC, USA: Government Printing Office. $p$. 90-91.

Mason, E. 1952. Food habitats and measurements of Hart Mountain antelope. Journal of Wildlife Management 16:387-389.

McArthur, E. D., and A. P. Plummer. 1978. Biogeography and management of western native shrubs: a case study, section Tridentatae of Artemisia. Great Basin Naturalist Memoirs 2:229-243.

Miller, R. F., and L. E. Eddleman. 2000. Spatial and temporal changes of sagegrouse habitat in the sagebrush biome. Corvallis, OR, USA: Oregon State University, Oregon Agricultural Experiment Station Technical Bulletin 151. $35 \mathrm{p}$.

Miller, R. F., T. J. Svejcar, and N. E. West. 1994. Implications of livestock grazing in the Intermountain sagebrush region: plant composition. In: M. Vavra, W. A. Laycock, and R. D. Pieper [EDS.]. Ecological implications of livestock herbivory in the West. Denver, C0, USA: Society of Range Management. p. 101-146.

Morris, M. S., R. G. Kelsey, and D. Griggs. 1976. The geographic and ecological distribution of big sagebrush and other woody Artemisia in Montana. Proceedings of the Montana Academy of Science 36:56-79.

Ponzetti, J. M., And B. P. McCune. 2001. Biotic soil crusts of Oregon's shrub steppe: community composition in relation to soil chemistry, climate, and livestock activity. The Bryologist 104:212-225.

Shipley, L. A., T. B. Davila, N. J. Thines, and B. A. Elias. 2006. Nutritional requirements and diet choices of the pygmy rabbit (Bachylagus idahoensis): a sagebrush specialist. Journal of Chemical Ecology 32:2455-2474.

TISDALE, E. W. 1994. Wyoming big sagebrush SRM 403. In: T. N. Shiflet [ED.]. Rangelands cover types of the United States. Denver, C0, USA: Society of Range Management. p. 42-43.

Wallestead, R. O., J. G. Peterson, and R. L. Eng. 1975. Foods of adult sage grouse in central Montana. Journal of Wildlife Management 39:628-630.

West, N. E., R. J. Tausch, K. H. Rea, and P. T. Tueller. 1978. Taxonomic determination, distribution, and ecological indicator values of sagebrush within the pinyon-juniper woodlands of the Great Basin. Journal of Range Management 31:87-92.

West, N. E., AND J. A. Young. 2000. Intermountain valleys and lower mountain slopes. In: M. G. Barbour and W. D. Billing [EDs.]. North American terrestrial vegetation. Cambridge, United Kingdom: Cambridge University Press. p. 255-284.

Winward, A. H. 1980. Taxonomy and ecology of sagebrush in Oregon. Corvallis, OR, USA: Oregon State University, Oregon Agricultural Experiment Station Bulletin 642. $15 \mathrm{p}$.

Winward, A. H., And E. W. Tisdale. 1977. Taxonomy of the Artemisia tridentata complex in Idaho. Moscow, ID, USA: University of Idaho, Forest, Wildlife, and Range Experiment Station Bulletin 15. 15 p. 